\title{
PERANCANGAN SISTEM INFORMASI KOPERASI SMK NEGERI 1 KOTA PARIAMAN
}

\author{
Firdaus, Ade Pratama, Irsyadunas \\ Program Studi Pendidikan Informatika STKIP PGRI Sumatera Barat \\ Firdausbro73@gmail.com
}

\begin{abstract}
Cooperative in SMK 1 Pariaman City is cooperative that is on developing and have a routine enough high, but the process processing the data still using a manual system. In overcoming these problems an information system is needed in order to simplify the performance of cooperative devices, then the authors designed a cooperative information system at SMK Country 1 city Pariaman. There are several methods in this writing such as research methods to develop an system the interactive model used has several stages in forming an information system, namely system planning, system analysis, system design and application of system. The result of this writing is a cooperative information system design that uses the testing phase with the blackbox method, namely system testing that focuses on functional spesifications and software and the tester can define a collection of input conditions in testing the functional specifications of the program.
\end{abstract}

Keywords: Information, System, Cooperative.

PENDAHULUAN

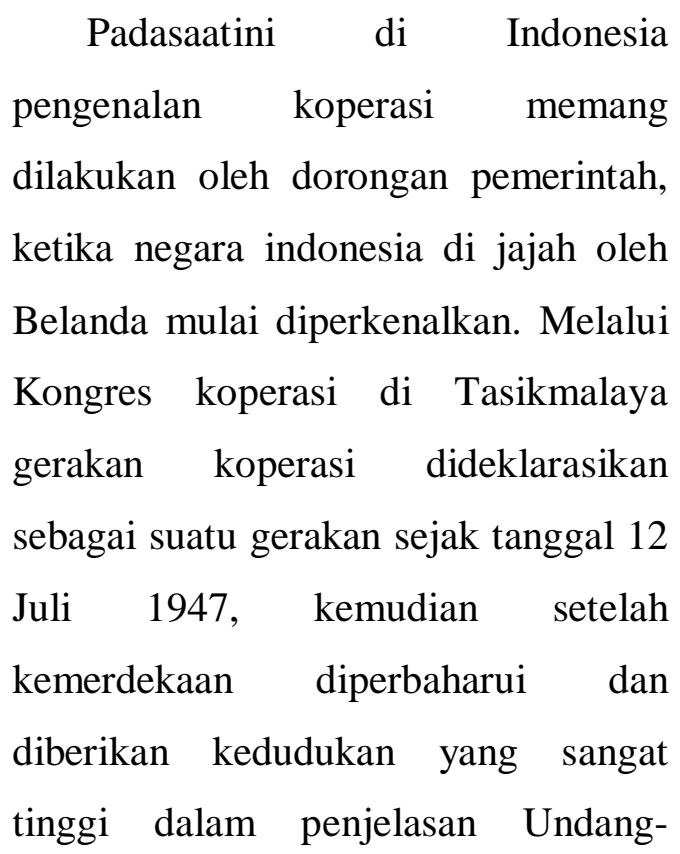

Undang Dasar. Atas dasar itulah kemudian melahirkan berbagai penafsiran bagaimana harus mengembangkan koperasi. Sejarah perkembangan koperasi di Indonesia telah mencatat tiga pola pengembangan koperasi.

Pada SMK Negeri 1 Pariaman saat ini mempunyai kegiatan koperasi yang signifikan, tetapi pengelolaan datadatanya masih menggunakan buku dalam menulis nama anggota yang meminjam. Salah satu penggunaan 
sistem yang masih manual tersebut adalah pencatatan transaksi masih menggunakan microsoft excel, sehingga seringkali menimbulkan kemungkinan terjadinya kendala. Hal itu disebabkan oleh pengolahan data transaksi masih secara manual. Pendataan secara manual menyebabkan pengolahan data masih lambat dan kurang efektif, selain itu belum adanya system informasi yang efektif.

\section{METODE PENELITIAN}

Perancangan pada penelitian ini menggunakan sistem SDLC (Software Development Life Cycle) mempunyai empat dalam pembentukan sistem informasi yaitu: Perencanaan, Analisis, PerancanganDesain, dan Penerapan Implementasi Sistem, (Nurmi, 2016).

\section{Perencanaan Sistem}

Perencanaan ini dilakukan untuk mengidentifikasi sistem yang perlu dan strategis dalam organisasi. Bertujuan melihat kegunaan dari teknologi informasi sehingga dapat mengembangkan proyek dan mensupport sistem tujuan dari proyek tersebut. Sebelum melakukan pengembangan pada dasarnya membutuhkan kebijakan dari manajemen puncak. Apabila tidak ada dukungan dari manajemen maka pengembangan suatu sistem tidak sesuai dengan tujuan (Nurmi, 2016).

2. Analisis Sistem

Menganalisis sistem merupakan langkah utama dari membangun sistem informasi. Analysis membentuk sebuah aliranproses diagram, dimana data dan informasi dinputkan, lalu diolah sehingga menghasilkan output yang dibutuhkan oleh manajemen.

3. Rancangan Sistem

Padaproses ini model perancangan system yang digunakan adalahUnfied Modeling Language. Perancangan system dengan UML menggunakan beberapa bentuk diagram yaitu :

1) Diagram Use Case

2) Diagram Activity

3) Diagram Sequence

4) Diagram Class

4. Implementasi

Implementasi sistem merupakan tahap pengevaluasian untuk perancangan sistem informasi koperasi 
bagi user. Sistem memerlukan maintenance agar system informasi tersebut berjalan sesuai dengan harapan user atau pengguna.

5. Analisis Sistem yang Sedang Berjalan

Pada pengamatan secara langsung dapat diidentifikasi kondisi dan beberapa kekurangan serta kendala pada system koperasi tersebu. Berdasarkan hasil pengamatan dapat diketahui bahwa pengelolaan data simpan pinjam yang dilakukan bersifat manual. Sehingga mengakibatkan kesalahan yang signifikan terhadap rekap data peminjaman dan butuh waktu lama pada proses simpan pinjam.

\section{Perancangan Sistem}

Sistem yang dirancang menggunakan metode UML, yang memiliki fungsi pada proses pengembangan dan pendokumentasian system berbasis Object-Oriented. Metode tersebut juga memberikan standar sebuah penulisan system blue print, yang meliputi alur bisnis, penulisan bahasa pemprograman yang spesifik, alur komponen dan database yang dibutuhkan system (Sugiarti, 2016).

Use Case Diagram

Diagram Use Case adalah sebuah fungsional yang diharapkan apa yang diperbuat didalam system (Firdaus, 2017).

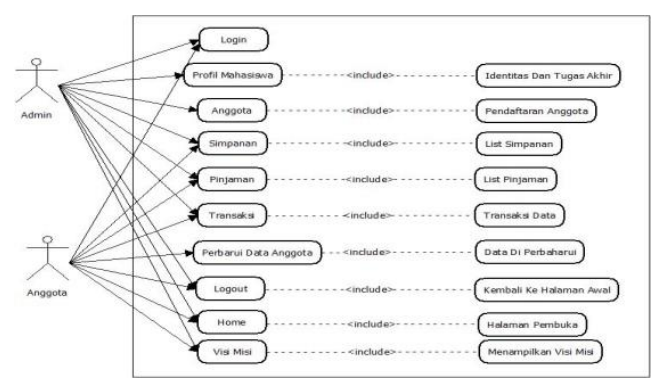

Gambar 1. Use Case Diagram

Activity Diagram

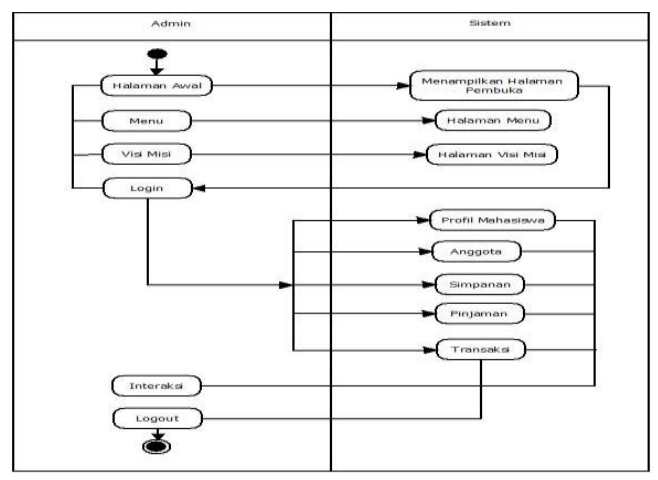

Gambar2. Activity Diagram 
Sequence Diagram

1. Sequence diagram login

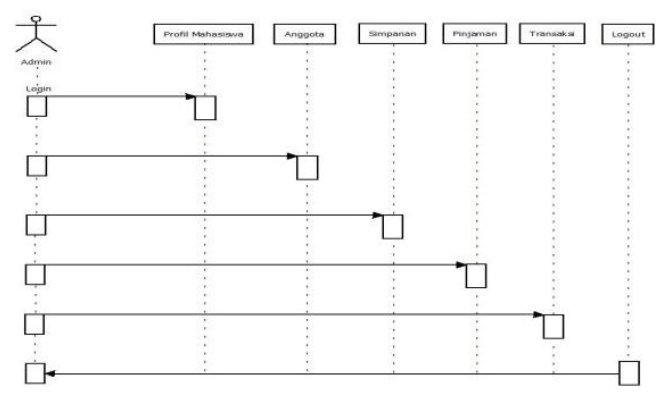

Gambar 3. Sequence Diagram Login

2. Sequence diagram anggota

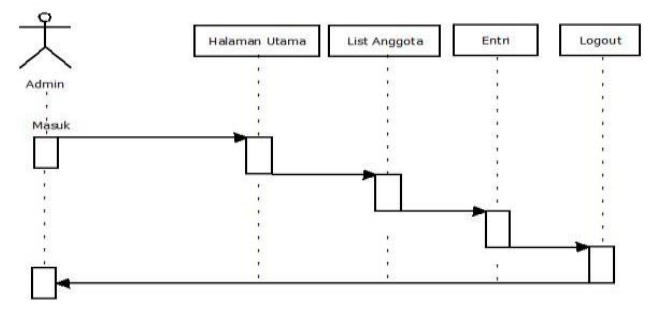

Gambar 4. Sequence Diagram Anggota

3. Sequence diagram

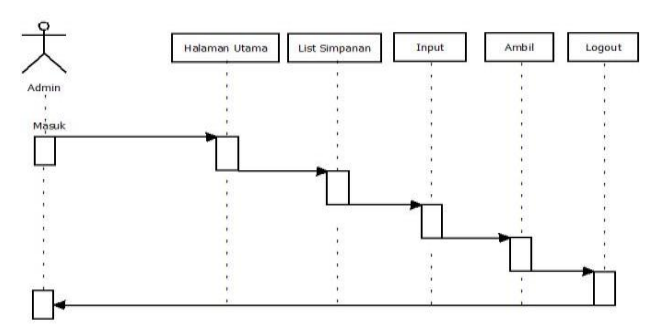

Gambar 5. Sequence Diagram Simpanan
Class Diagram

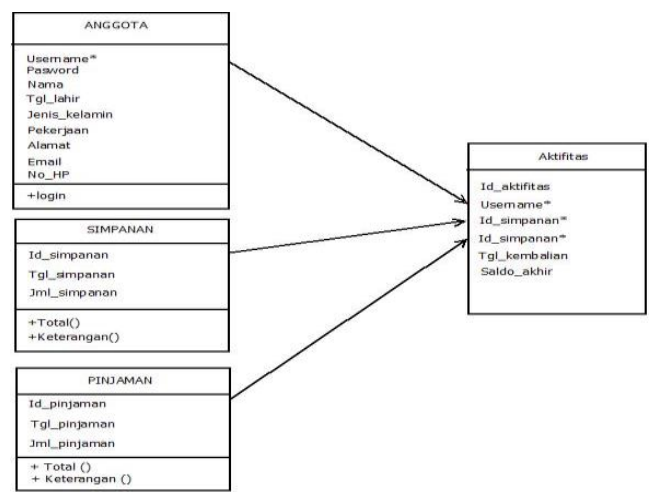

Gambar 6. Class Diagram

\section{HASIL DAN PEMBAHASAN}

Menurut Reza Sartika (2015) dalam jurnalnya yang berjudul perancangan sistem informasi simpan pinjam kopkar mandiri A.Riva'i berbasis web. Dimana berdasarkan penelitian yang dilakukan, didapatkan hasil bahwa website sistem informasi koperasi bisa membantu memberikan kemudahan bagi administrasi koperasi dalam mengelola semua transaksi simpan pinjam secara lebih cepat dan tepat. Kemudian website tersebut juga dapat memberikan informasi yang akurat kepada anggota dengan cepat dan mempermudah anggota mengontrol pinjaman dan angsuran mereka. Lalu website tersebut juga mempermudah calon anggota dalam 
melakukan proses pendaftaran. Sehingga didapatkan hasil sistem yang sangat efektif digunakan.

Menurut Nurlaila Hasyim (2017) Jurnal dengan judul rancang bangun sistem informasi koperasi berbasis web pada koperasi warga baru MTsN 17 Jakarta. Dimana sistem perancangan sistem informasi ini diperoleh hasil melalui tahapan penelitian, yaitu dengan menggunakan penyimpanan database input, edit, delete dan view pada sistem informasi koperasi dapat memudahkan proses pengolahan data transaksi simpan pinjam toko dan barang. Kemudian dengan sistem informasi koperasi yang dibangun, pengurus dan anggota lebih memudahkan pembuatan laporan dalam melakukan kontrol transparansi angsuran pinjaman, jumlah simpanan (simpanan pokok, simpanan wajib, dan simpanan sukarela). Lalu dari sistem yang dibuat juga memudahkan anggota memperoleh informasi tanpa harus datang ke koperasi.

Menurut penelitian yang dilakukan Nova anggraini (2012) dengan judul Perancangan Sistem
Informasi Simpan Pinjam di KUD Mandiri Bayongbong. Dimana sistem informasi koperasi simpan pinjam dapat mempermudah kinerja Bayongbong. Pada aplikasi tersebut terdapat menu traksaksi perorangan sehingga akan dapat dengan mudah dan efisien mencari ataupun mengetahui baik data anggota lama maupun anggota baru yang melakukan transaksi. Dengan adanya Sistem informasi simpan pinjam KUD semua kebutuhan terpenuhi seperti mengetahui data anggota, data transaksi mulai dari simpan pinjam serta angsuran yang dilakukan oleh anggota. Dengan demikian petugas dapat bekerja lebih cepat,efektif,akurat dan efisien karena semua data diolah oleh sistem.

Implementasi Sistem

Implementasi sistem merupakan proses penerapan perancangan program yang dibuat pada ketika sistem akan diterapkan. Oleh karena itu pengimplementasian sistem termasuk bagian dari proses pengembangan system. Dalam pelaksanaan implementasi sistem 
dibutuhkan pemrograman komputer untuk merancang interface serta kesesuian sistem yang dibangun dengan kode pemrograman.

Implementasi Perangkat Lunak

Perangkat lunak (Software) berperan penting dalam proses mengaplikasikan hardware. Komponen perangkat keras dapat berjalan ketika adanya perangkat lunak. Untuk mendukung aplikasi koperasi dapat berfungsi dengan baik dan efektif dibutuhkan baik perangkat lunak maupun perangka keras.

Implementasi Perangkat Keras

Perangkat keras (hardware) merupakan komponen peralatan yang melakukan tugasnya dengan membentuk sebuah sistem komputer serta peralatan lainnya. Perangkat keras yang digunakan dalam perancangan sistem informasi koperasi SMK Negeri 1 Kota pariaman.
1. Form Menu Utama

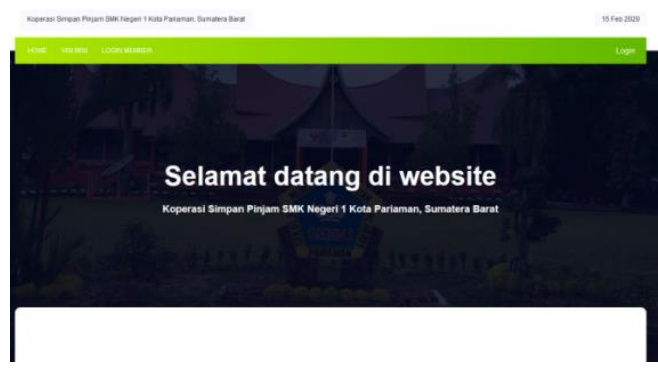

Gambar 7. Menu Utama

Gambar tersebut merupakan gambar Interface dari menu utama, Dimana halaman tersebut tampil menu home, visi-misi untuk melihat visi dan misi dari koperasi SMK, login anggota untuk anggota dalam masuk kedalam program dan tombol login admin adalah berguna untuk admin dalam melakukan aktifitas.

\section{Form List Simpanan}

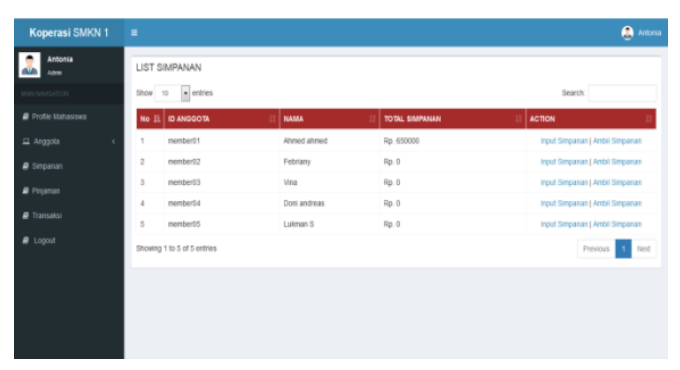

Gambar 8. List Simpanan

Gambar ini merupakan interface halaman list simpanan dimana tampilan tersebut menampilkan dari anggota yang meminjam yaitu nomor, 
id anggota, nama, total simpanan, action (input simpanan dan ambil simpanan).

\section{Form List Pinjaman}

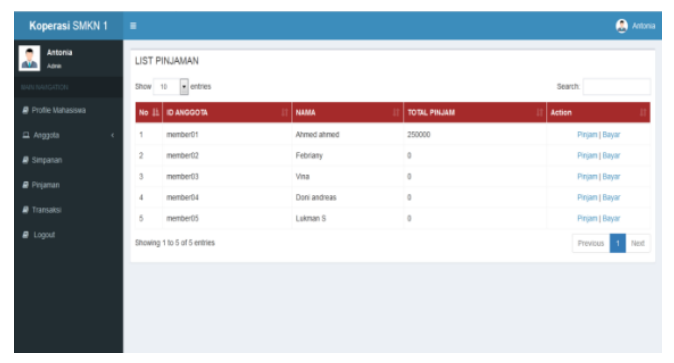

Gambar 9. List Pinjaman

Pada gambarini adalah list pinjaman yang terdapat didalamnya ada nomor, identitas dari anggota, nama anggota, total pinjam yang dilakukan oleh anggota.

\section{Form transaksi}

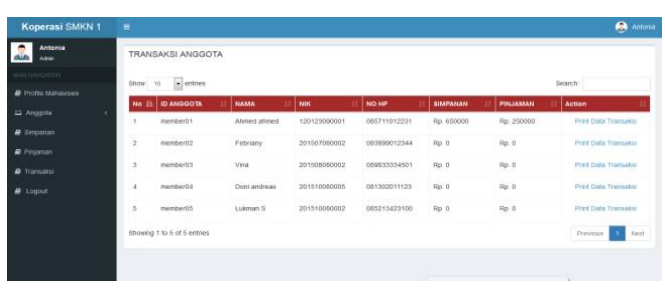

\section{Gambar 10. Form transaksi}

Tampilan transaksi terdapat didalamnya nomor, identitas anggota, nama, NIK dari anggota, nomor hanphone dari anggota, simpanan yang dilakukan anggota, pinjaman yang dilakukan anggota dan aksi.
5. Form print transaksi

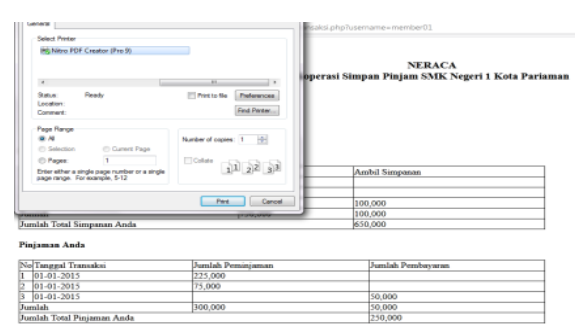

Gambar 11. Form print transaksi Tampilan print transaksi terdapat adalah tampilan dari transaksi anggota yang terdapat didalamnya nomor, tanggal transaksi anggota dan admin, jumlah peminjaman, jumlah pembayaran, jumlah simpanan dan ambil simpanan.

\section{Tahap Pengujian Sistem}

Pada tahap pengujian dalam penelitian ini menggunakan black box methoduntuk mengetahui apakah sistem informasi dapat berjalan sesuai dengan kebutuhannya. Pengujian ini bertujuan untuk mengetahui layak atau tidaknya sistem untuk digunakan.

\section{Rencana Pengujian}

Rencana pengujian dari program tersebut ada beberapa tabel yang akan dibuat dalam perencanaan tersebut seperti tabel Login didalamnya 
terdapat kelas uji, detail pengujian dan jenis pengujian.

Berikutnya ada tabel halaman pendaftaran dan selanjutnya terdapat tabel halaman simpanan, dan terdapat juga tabel halaman pinjaman, pada tabel selanjutnya terdapat tabel halaman transaksi.

Pada pembahasan ini memiliki tujuan untuk menjelaskan Perancangan Koperasi SMK Negeri 1 Kota Pariaman. Dari hasil penelitian yang telah dilakukan sebelumnya bahwa belum terdapat sistem yang bisa mengelola data secara otomatis. Sistem Informasi Koperasi SMK Negeri 1 Kota Pariaman, petugas mengalami kesulitan dalam pengelolaan data anggota yang meminjam.Oleh sebab itu, diperlukan pembuatan system berupa system informasi koperasi ini. Dengan adanya Sistem Informasi Koperasi ini berharap dapat membantu petugas dalam pengelolaan data simpan pinjam dengan efektif dan efisien sehingga memudahkan petugas dalam pengelolaannya.

Sesuai dengan hasil penelitian sebelumnya yang dilakukan, jika penelitian ini diterapkan akan dapat mempermudah pengelolaan data koperasi lebih efisien dan efektif. Sehingga dapat mempermudah dan mempercepat tugas dari user saat pencariandan rekap data anggota, mencetak laporan.

Kesimpulan dari hasil dan pengujian yang dilakukan menjelaskan bahwa aplikasi yang dirancang telah memenuhi kebutuhan manajemen sesuai dengan yang diharapkan.

Pembahasan struktur sistem informasi koperasi SMK Negeri 1 Kota pariaman, terdiri dari input -prosesoutput disertai penjelasan-penjelasan tentang proses sistem informasi tersebut.

\section{KESIMPULAN}

Berdasarkan pembahasan dan penelitian yang dilakukan di koperasi SMK Negeri 1 Kota Pariaman tersebut maka dirancang suatu sistem informasi, dan kegunaannya antara lain:

1. Dengan adanya sistem informasi koperasi berbasis web dapat 
mempermudah pekerjaan

perangkat pada koperasi tersebut.

2. Dalam penelitian akan dihasilkan aplikasi simpan pinjam berbasis WEB.

3. Dari pengujian Blackboxdapat diketahui kebutuhan sudah terpenuhi oleh sistem informasi yang dirancang.

\section{DAFTAR PUSTAKA}

Firdaus. (2017). Perancangan Sistem Informasi Akuntasi Koperasi dan UMKM berbasis Technopreneur. Jurnal Riset Akuntansi dan Keuangan.depublish

Nova anggraini. (2012). Perancangan Sistem Informasi Simpan Pinjam di KUD Mandiri Bayongbong.

Nurlaila Hasyim. (2017). Rancang Bangun Sistem Informasi Koperasi Berbasis Web pada Koperasi Warga Baru MTsN 17 Jakarta.

Nurmi. (2016). Konsep Sistem Informasi.Padang:Sukabina.press.

Reza sartika. (2015). Perancangan Sistem Informasi Simpan Pinjam Kopkar Mandiri A. Rivai BerbasisWeb.Depublish

Sugiarti. (2016). Unfied Modeling Language.Depublish 